\title{
The Effect of Plasma Treatment on Tensile Strength of Ensete Ventricosum Fibres
}

Petr Hrabě, Miroslav Müller, Čestmír Mizera

Department of Material Science and Manufacturing Technology, Faculty of Engineering, Czech University of Life Sciences Prague, 16500 Prague 6. E-mail: hrabe@tf.czu.cz,muller@tf.czu.cz,mizera@tf.czu.cz

This study was focused on an effect of the plasma treatment on a mechanical behaviour of false banana's fibres (Ensete Ventricosum). The aim of the experiment was to describe the tensile strength of Ensete Ventricosum fibres which were modified by the plasma surface treatment. The fibres of Ensete Ventricosum, originally from Ethiopian region Hawassa, were used for this experiment. The fibres were prepared in the length of $100 \mathrm{~mm}$. The samples were modified by the plasma treatment. Plasma was generated from a plasma generator (Plasma Reactor KPR $200 \mathrm{~mm}$ RM 54) while supplying the reaction gas (oxygen) and maintaining the reactor's pressure at 0.1 Torr with the use of a vacuum pump. To determine the properties that depend on the discharge power and treatment time, the plasma treatment was conducted in the power range 200-350 $\mathrm{W}$ for 10-50 $\mathrm{s}$. The maximum tensile force was measured immediately after the plasma treatment to determine the ultimate strength. The ultimate strength and the deformation were determined by destructive tests using the tensile testing equipment (Labortech, MPTest 5.050, sensing unit AST type KAF $50 \mathrm{~N}$, Czech Republic) with a rate of deformation $5 \mathrm{~mm} \mathrm{~min}^{-1}$. Fracture surfaces of fibres were studied using a scanning electron microscope (Tescan Mira 3, Czech Republic). The samples were covered with a thin layer of gold using a sputter coater (Quorum Q150R ES, United Kingdom) before SEM observation.

Keywords: Agriculture, tensile strength, Plasma treatment, Surface modification, Scanning electron microscope

\section{Acknowledgement}

Supported by Internal grant agency of Faculty of Engineering, Czech University of Life Sciences Prague (Research on mechanical properties of multi-component polymer systems during their preparation, processing and application, 2016:31140/1312/3109).

\section{References}

[1] AlveS, C., FERrAO, P., M., C., SilvA, A., J., REIS, L., G., FREITAS, M., RODRIGUES, L., B. (2010). Ecodesign of automotive components making use of natural jute fiber composites. In: Journal of Cleaner Production, Vol. 18, pp. $313-327$.

[2] MIZERA, Č., HRABĚ, P., MÜLLER, M., HERÁK, D. (2016). Creep behaviour of the polymer composite with False Banana's fibres (Ensete Ventricosum). In: Manufacturing technology, Vol. 16, No. 4, pp. 188 - 192.

[3] KALIA, S., THAKUR, K., CELLI, A., KIECHEL, M.A., SCHAUER, C.L. (2013). Surface modification of plant fibers using environment friendly methods for their application in polymer composites, textile industry and antimicrobial activities. In: Journal of Environmental Chemical Engineering, Vol. 1, pp. 97-112.

[4] POOLE, A., J., CHURCH, J., S., HUSON, M., G. (2009). Environmentally sustainable fibers from regenerated Protein. In: Biomacromolecules, Vol. 10, pp. 1-8.

[5] WAMBUA, P., IVENS, J., VERPOEST, I. (2003). Natural fibres: can they replace glass in fibre reinforced plastics? In: Composites Science and Technology, Vol. 63, pp. 1259 - 1264.

[6] FARUK, O., BLEDZKI, A., K., FINK, H., P., SAIN, M. (2012). Biocomposites reinforced with natural fibers: 2000-2010. In: Progress in Polymer Science, Vol. 37, pp. 1552 - 1596.

[7] HERRERA-FRANCO, P., J., VALADEZ-GONZA'LEZ, A. (2005). A study of the mechanical properties of short natural-fiber reinforced composites. In: Composites: Part B, Vol. 36, pp. 597 - 608.

[8] ALKBIR, M., F., M., SAPUAN, S., M., NURAINI, A., A., ISHAK, M., R. (2016.) Fibre properties and crashworthiness parameters of natural fibre reinforced composite structure. In: Composite Structures, Vol. 148, pp. 59 73.

[9] SHARIFAH, H., A., MARTIN, P., A. (2004). The effect of alkalization and fiber alignment on the mechanical and thermal properties of kenaf and hemp bast fiber composites: Part 1 - polyester resin matrix. In: Composites Science and Technology, Vol. 64, pp. 1219 - 30. 
[10] TSEHAYE, Y., KEBEBEW, F. (2006). Diversity and cultural use of Enset (Enset ventricosum (Welw.) Cheesman) in Bonga in situ Conservation Site, Ethiopia. In: Ethnobotany Research and Applications. Vol. 4, pp. 147 157.

[11] BORUVKA, M., NGAOWTHONG, CH., CERMAN, J., LENFELD, P., BRDLIK, P. (2016). The Influence of Surface Modification Using Low-Pressure Plasma Treatment on PE-LLD/ $\alpha$-Cellulose. In: Composite Properties, Vol. 16, No. 1, pp. $29-34$.

[12] MÜLLER, M., HERÁK, D., VALÁŠEK, P. (2013). Degradation limits of bonding technology depending on destinations Europe, Indonesia. In: Tehnicki Vjesnik-Technical Gazette, Vol. 20, No. 4, pp. 571 - 575.

[13] VALÁŠEK, P., MÜLLER, M. (2015). Abrasive wear in three-phase waste-based polymeric particle composites. In: Tehnicki Vjesnik-Technical Gazette, Vol. 12, No. 2, pp. 257 - 262.

[14] VALÁŠEK, P., MÜLLER, M. (2012). Polymeric particle composites with filler saturated matrix. In: Manufacturing Technology, Vol. 12, No. 13, pp. $272-276$.

[15] NECHWATAL, A., MIECK, K-P., REUßMANN, T. (2003). Developments in the characterization of natural fibre properties and in the use of natural fibres for composites. In: Composites Science and Technology, Vol. 63, pp. $1273-1279$.

[16] MIZERA, Č., HERÁK, D., HRABĚ, P., MÜLLER, M., KABUTEY, A. (2016). Effect of Length of False Banana Fibre (Ensete ventricosum) on Mechanical Behaviour under Tensile Loading. In: Scientia Agriculturae Bohemica, Vol. 47, Issue 2, pp. $90-96$.

[17] VALADEZ-GONZA LEZ, A. (2005). A study of the mechanical properties of short natural-fiber reinforced composites. In: Composites: Part B Vol. 36, pp. 597 - 608. 